\title{
Perlindungan pohon induk jernang (Daemonorops spp.) di Mandiangin, Jambi
}

\author{
Revis Asra ${ }^{1 *}$, Ade Octavia ${ }^{2}$, \& Lisna ${ }^{3}$ \\ ${ }^{1}$ Fakultas Sains dan Teknologi, Universitas Jambi, Indonesia \\ ${ }^{2}$ Fakultas Ekonomi dan Bisnis, Universitas Jambi, Indonesia \\ ${ }^{3}$ Fakultas Peternakan, Universitas Jambi, Indonesia \\ *revisasra@unja.ac.id
}

\begin{abstract}
Jernang rattan is one of the superior products of Jambi Province, besides palm and rubber, unlike most rattan which is used from the stem, but the used of jernang is the red resin. Jernang has the potential to be integrated in rubber plantations, so it is the right solution to improve the economy of rubber farmers in Liam Lestari Village Mandiangin District, Sarolangun District. The difficulty of getting old seeds as a source of seedlings is a major obstacle in jernang cultivation. In Liam Lestari village, one rubber farmer was found who had made clear integration, but the jernang fruit was often stolen, so that no old seeds were used for seedlings. Community Service Activities with a scheme of Regional Superior Product Development Program (PPPUD) is one solution to overcome the difficulties of seedlings in Mandiangin. The service method used is Participatory Rural Apraisal. PPPUD activities involve the Jernang Lestari farmer group. Based on the results of dedication by protecting the parent tree through fencing with bulian wood, it can overcome the problem of theft of jernang fruit.
\end{abstract}

\begin{abstract}
Abstrak Rotan jernang termasuk salah satu produk unggulan Provinsi Jambi, disamping sawit dan karet, tidak seperti kebanyakan rotan dimana yang dimanfaatkan dari bagian batang, tetapi yang dimanfaatkan dari jernang adalah resin merah yang ditemukan pada buah. Jernang berpotensi untuk diintegrasi di kebun karet, sehingga merupakan solusi yang tepat untuk meningkatkan perekonomian petani karet di Desa Liam Lestari Kecamatan Mandiangin, Kabupaten Sarolangun, karena petani dapat memperoleh keuntungan ganda yaitu dari getah karet dan getah resin merahnya. Sulitnya mendapatkan biji tua sebagai sumber bibit merupakan kendala utama dalam budidaya jernang. Di Desa Liam Lestari ditemukan satu orang petani karet yang telah melakukan integrasi jernang namun buah jernangnya sering dicuri orang, sehingga tidak diperoleh biji tua untuk bibit. Kegiatan Pengabdian Pada Masyarakat dengan skim Program Pengembangan Produk Unggulan Daerah (PPPUD) merupakan salah satu solusi untuk mengatasi kesulitan bibit di Mandiangin. Metode pengabdian yang digunakan yaitu Participatory Rural Apraisal (PRA). Kegiatan PPPUD melibatkan kelompok tani Jernang Lestari. Berdasarkan hasil pengabdian dengan melakukan perlindungan pohon induk melalui pemagaran dengan kayu bulian, dapat mengatasi masalah pencurian terhadap buah jernang.
\end{abstract}

Keywords: jernang rattan (Daemonorops spp.); jernang seeds; product quality; cultivation; fencing

\section{¿ OPEN ACCESS}

Citation: Asra, R., Octavia, A., \& Lisna. (2020). Perlindungan pohon induk jernang (Daemonorops spp.) di Mandiangin, Jambi. Riau Journal of Empowerment, 3(1), 39-47. https://doi.org/10.31258/raje.3.1.39-47

Paper type: Community service

Received: 2019-07-31 Revised: 2019-12-19 Accepted: 2019-12-30

Language: Bahasa Indonesia (id)

Funding: Direktorat Riset dan Pengabdian Masyarakat, Direktorat Jenderal Penguatan Riset dan Pengembangan Kementerian Riset, Teknologi, dan Pendidikan Tinggi. Perjanjian Pendanaan Pelaksanaan Program Pengabdian Kepada Masyarakat skim Program

Pengembangan Produk Unggulan Daerah Nomor 013/SP2H/PPM/DRPM/2018

ISSN 2623-1549 (online), 2654-4520 (print)

C 2019 Revis Asra et al. Author(s) retain the copyright of article published in this journal, with first publication rights granted to Riau Journal of Empowerment. The article is licenced under Creative Commons Attribution 4.0 International License. This license permits unrestricted use, distribution, and reproduction in any medium, provided the original author and source are credited. 


\section{PENDAHULUAN}

Rotan jernang adalah salah satu tumbuhan yang berpotensi sebagai produk unggulan Jambi, disamping sawit dan karet karena sumber plasma nutfah rotan jernang ini banyak ditemukan di pulau Sumatera termasuk di Provinsi Jambi. Namun Jambi memiliki potensi yang besar untuk plasma nutfah yang satu ini. Berdasarkan hasil penelitian Asra et al. (2014), terhadap diversitas (keanekaragaman) genetik pada beberapa populasi rotan jernang di Provinsi Jambi dan Provinsi Riau baik yang berada di kawasan konservasi maupun pada kawasan hutan sekunder, ditemukan bahwa keanekaragaman genetik tertinggi ditemukan di kawasan hutan sekunder Sepintun Kabupaten Sarolangun, Provinsi Jambi. Jika potensi ini digarap secara maksimal maka Jambi memiliki produk unggulan yang tidak ditemukan di daerah lainnya.

Resin merah yang dihasilkan dari rotan jernang, secara lokal di Jambi dikenal dengan lulun, namun dari perdagangan Internasional dikenal dengan palem darah naga (dragon's blood palm). Hasil wawancara dengan masyarakat desa diperoleh informasi bahwa rotan jernang semakin lama semakin sedikit dan jarak tempuh pengambilan jernang semakin jauh dari desa, serta semakin sedikit jumlah jernang yang berhasil dikumpulkan oleh pemburu jernang, artinya keberadaan jernang di hutan alam semakin langka. Hal ini disebabkan oleh berkurangnya hutan alam karena telah berubah menjadi perkebunan karet dan kelapa sawit. Disamping itu upaya budidaya sangat minim dilakukan, karena sulitnya mencari biji tua sebagai sumber bibit, karena dalam pencarian buah jernang di hutan alam berlaku hukum rimba, dimana siapa yang cepat dialah yang dapat. Akibatnya buah jernang tua sangat susah ditemukan. Hal ini mengakibatkan keberadaan dari tanaman Jernang semakin lama semakin langkah (Lestari, 2017).

Salah satu sumber penghasilan masyarakat di Jambi yang bermukim di desa-desa adalah mencari buah jernang di hutan alam. Luasan hutan yang setiap tahun berkurang berdampak secara langsung terhadap hasil yang mereka peroleh. Disamping itu pola pemanenan yang tidak lestari, dimana para pencari jernang selalu memanen buah jernang yang masih muda, karena getah jernang lebih banyak diperoleh pada buah yang muda ini. Hal ini menyebabkan kesempatan buah menjadi tua untuk bergenerasi menghasilkan bibit menjadi tidak ada. Hal ini merupakan faktor utama yang menyebabkan produksi jernang di Jambi menurun drastic. Selanjutnya Sulasmi et al. (2012) menyatakan bahwa penyebab menurunnya dan langkanya produksi getah jernang karena semakin ekspansifnya pengembangan perkebunan disamping tidak optimalnya sistem regerasi alami dan pola pemanenan dengan cara menebang pohon jernang tersebut. Sementara menurut Asra et al. (2014), Resin jernang adalah sumber penghasilan bagai masyarakat di Mandiangin ketika musim berbuah jernang tiba. Mereka akan mencari buah jernang di hutan sekunder di sekitar lingkungan mereka.

Salah satu desa di Provinsi Jambi yang memiliki rotan jernang adalah Desa Liam Lestari yang terletak di Kecamatan Mandiangin, Kabupaten Sarolangun. Ditemukan 3 rumpun jernang yang diintegrasi dengan kebun karet di desa ini. Namun buah jernang di desa ini sering terjadi pencurian, akibatnya budidaya jernang juga tidak dapat dilakukan, sementara permintaan akan bibit jernang saat ini sangat tinggi.

Budidaya dan perlindungan jernang Desa Liam Lestari merupakan tindakan yang tepat dalam upaya untuk meningkatkan produksi rotan jernang dan perekonomian rakyat petani karet. Oleh karena itu dilakukan upaya untuk melindungi pohon induk jernang melalui pemagaran. Perlindungan pohon induk jernang dilakukan dengan tujuan untuk menghindari dan mencegah pencurian buah jernang, sehingga buah jernang dapat dipanen pada saat telah tua dan bijinya merupakan sumber bibit nantinya. 
Kegiatan Pengabdian Pada Masyarakat ini telah dilaksanakan di Desa Liam Lestari Kecamatan Mandiangin, Kabupaten Sarolangun, bersama Kelompok Tani Jernang Lestari (Desa Liam Lestari) Pemilihan lokasi ini didasarkan karena sebagian besar masyarakat ini merupakan petani karet dan di daerah ini memiliki sumber plasma nutfah rotan jernang yang berpotensi untuk dikembangkan. Metode pengabdian yang digunakan adalah Participatory Rural Apraisal (PRA), yaitu metode pendidikan pada masyarakat.

Langkah pertama dalam kegiatan ini adalah sosialisasi yang dilakukan pada Kelompok Tani Jernang Lestari, Berdasarkan informasi dari Ketua Kelompok Tani Jernang Lestari, dampak positif dari kegiatan sosialisasi adalah bahwa masyarakat yang bukan anggota kelompok tani, juga terinspirasi untuk melakukan budidaya jernang di kebun karetnya. Dengan banyaknya masyarakat yang melakukan budidaya jernang, maka produksi jernang kedepannya semakin tinggi, sehingga akan meningkatkan kesejahteraan para petani jernang.

\section{HASIL DAN KETERCAPAIAN SASARAN}

Target luaran yang diharapkan dalam pelaksanaan Pengabdian Kepada Masyarakat dalam skim PPPUD (Program Pengembangan Produk Unggulan Daerah) di Mandiangin, Provinsi Jambi, adalah untuk menumbuhkan minat masyarakat petani karet di Mandiangin dalam budidaya jernang. Untuk mendapatkan buah jernang tua sebagai sumber bibit maka dilakukan pencegahan pencurian buah jernang dengan melakukan perlindungan pohon induk. Perlindungan pohon induk dilakukan dengan cara pemagaran menggunakan kayu besi/kayu bulian bertujuan supaya pagar yang dibuat bisa tahan lama.

\section{Sosialisasi Kegiatan PPPUD}

Sosialisasi kegiatan Pengabdian Masyarakat PPPUD (Program Pengembangan Produk Unggulan Daerah) dengan tujuan, untuk menginformasikan kepada masyarakat khususnya Kelompok Tani Jernang Lestari, bahwa budidaya jernang di perkebunan karet penting untuk dilakukan. Pada kesempatan ini masyarakat juga diberi penjelasan bahwa dengan menanam jernang, mereka tidak perlu lagi mencari jernang di hutan alam, yang membutuhkan biaya cukup besar (Rp.500.000) dan hasil yang tidak seberapa (Rp.700.000).

Menurut Yetty et al. (2013), sejak zaman dahulu rotan jernang merupakan salah satu komoditas yang diperdagangkan, akan tetapi tingkat produktivitas jernang sekarang ini sedang mengalami penurunan hal tersebut ditunjukkan pada tahun 1960an, setiap pengekstrak jernang dapat menghasilkan getah jernang setiap musim berbuah sebanyak 30-50 kg, maka sekarang ini hanya dapat menghasilkan getah jernang $5-15 \mathrm{~kg}$. Demikian juga jumlah populasi jernang menjadi semakin berkurang akibat kerusakan habitatnya. Budidaya jernang merupakan salah satu upaya yang dapat dilakukan. Dengan adanya kegiatan sosialisasi ini diharapkan dapat membuka wawasan para kelompok tani tentang Integrasi jernang di perkebunan karet yang lebih efisien dibanding dan menguntungkan dari pada mencari jernang. Kegiatan sosialisasi ini diikuti oleh enam orang Kelompok Tani, yang dilaksanakan pada hari Jumat. Karena hari Jumat merupakan hari pasar, sehingga anggota yang punya waktu untuk mengikuti kegiatan menjadi terbatas (Gambar 1). 


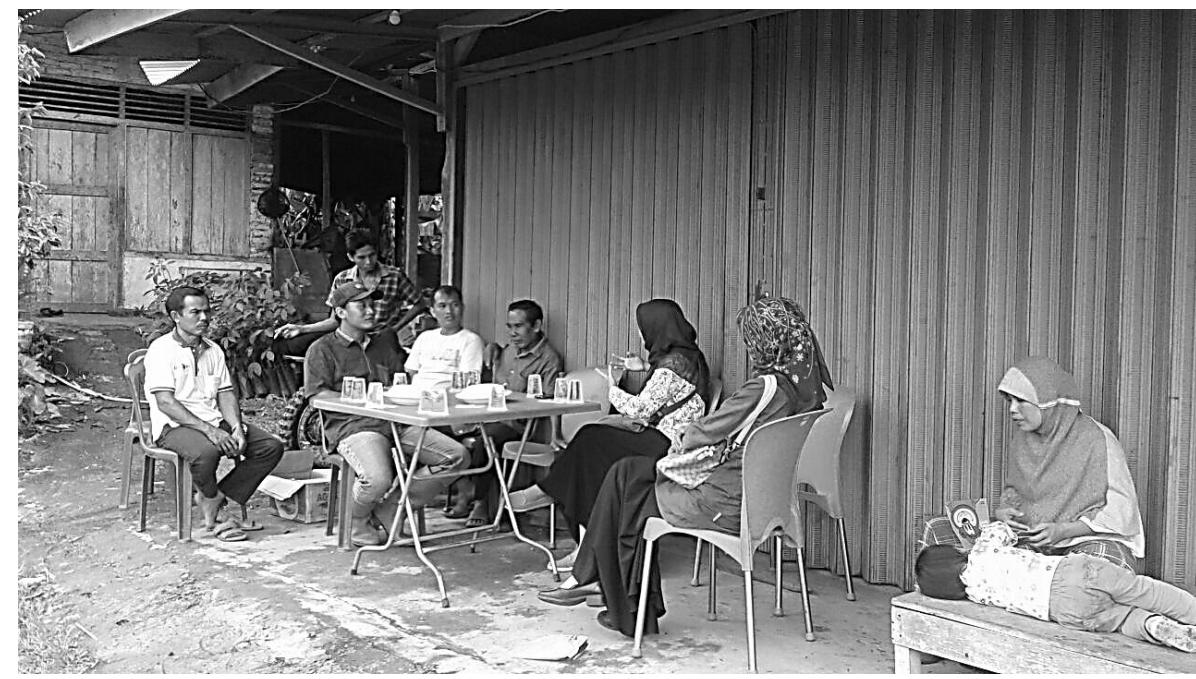

Gambar 1. Sosialisai kegiatan perlindungan pohon induk jernang di Desa Liam Lestari

Pada kegiatan sosialisasi Ketua Tim Pengabdian juga menghimbau anggota kelompok tani untuk tidak melakukan kecurangan-kecurangan dalam mengolah getah jernang. Jika kualitas getah jernang di Mandiangin tetap baik, maka harga jual akan baik, namun apabila mencampur getah jernang dengan damar mata kucing atau batu bata, maka kualitas getah jernang akan rendah dan nilai jual getah juga akan rendah sekali. Oleh karena itu kejujuran sangat penting dalam mengolah getah jernang.

\section{Pemanfaatan jernang}

Pemanfaatan jernang di Provinsi Jambi telah dilakukan sejak zaman dahulu. Secara tradisional jernang dimanfaatkan untuk obat luka, pilis (untuk obat bagi ibu yang baru melahirkan), pewarna ambung (keranjang rotan), sakit perut dan untuk pewarna kue. Jernang dimanfaatkan sebagai pewarna dan dalam industri obat-obatan. Menurut Purwanto et al. (2005), bahwa industri kertas, kayu, alat-alat batu, keramik dan marmer memanfaatkan warna merah pada jernang sebagai bahan baku pewarnanya. Sementara dalam industry farmasi, jernang berfungsi dalam penyembuh luka, antifungal, antibakteri, antitumor dan antioksidan (Gupta et al., 2008; Waluyo et al., 2015).

Di Eropa, resin merah dimanfaatkan untuk diare dan disentri, sementara di Malaysia juga dimanfaatkan untuk obat sakite perut dan di Yunani dimanfaatkan untuk obat sakit mata. (Yetty et al., 2013). Banyaknya nilai manfaat dari jernang ini maka, jernang dalam perdagangan bernilai ekonomi tinggi. Di daerah Bireun (Aceh), harga buah segar jernang mencapai Rp.400.000/kg, sementara untuk buah yang berukuran kecil yang baru mekar dari tandan bunga dinilai seharga Rp.70.000. sampai Rp.100.000/kg., sedangkan untuk harga getah/resin jernang mencapai Rp.5.000.000 (Ridhwan et al., 2018). Sementara di Mandiangin (Jambi) harga buah jernang mencapai Rp.500.000.

Disamping nilai ekonomis, rotan jernang juga berungsi untuk melindungi lingkungan di sekitar habitatnya, karena rotan jernang membutuhkan adanya pohon rambatan sebagai media untuk merambat ke atas dalam mencari cahaya matahari. Banyaknya manfaat yang dimiliki oleh tanaman Jernang mengakibatkan harga jualnya juga tinggi. Harga dari getah Jernang di tingkat petani pasar lokal berkisar antara Rp.400.000-Rp.800.000 bahkan ada yang mencapai harga Rp.30.000.000/kilogramnya, sedangkan untuk di pasar luar negeri misalnya Singapura harga jualnya mencapai US\$ 30/kilogram. Harga jual tersebut bergantung pada kelas 
kualitasnya. Semakin murni getah jernang yang dihasilkan maka semakin tinggi pula harga jualnya, sebaliknya semakin banyak campuran pada getah jernang semakin rendah pula harga jualnya (Purwanto et al., 2009; Kementerian Kehutanan Republik Indonesia, 2013; Matangaran \& Puspitasari, 2012; Hisan, 2012).

\section{Pelestarian jernang}

Hambatan lain dalam budi daya jernang adalah tingginya keanekaragaman genetik jernang liar yang ada di hutan (Asra et al., 2018), masyarakat khawatir jernang mereka tanam nantinya tidak berbuah. Selain itu karena tingginya keanekaragaman genetik jernang liar yang ada di hutan, ini menjadi salah satu hambatan dalam budi daya jernang (Asra et al., 2018). Masyarakat di desa Liam Lestari belum dapat membedakan jenis kelamin batang jernang pada saat penanaman, sehingga mereka khawatir jernang yang mereka tanam berjenis kelamin jantan dan tidak dapat berbuah. Rasio seks jernang secara alami adalah 1:1 yaitu jumlah antara jantan dan betina sama banyak di hutan alami. Namun demikian bisa juga terjadi penyimpangan rasio seks jernang jantan dan betina yang dibudidayakan yaitu 1:1,2 (Asra et al., 2012).

Jernang mulai berbuah setelah berumur 2 tahun, namun baru menghasilkan getah jernang setelah berumur 5 tahun (Winarni et al., 2004). Satu rumpun jernang secara umum terdiri atas 5-20 individu (Balai Konservasi Sumber Daya Alam Jambi, 2010). Rotan jernang adalah tumbuhan endemik di Sumatra. Spesies tersebut tumbuh pada jenis tanah PMK, di dataran rendah, dan $\mathrm{pH}$ tanah asam berkisar 4-6, curah hujan berkisar 1000-2300 mm, suhu udara berkisar 24-32oC, kelembapan berkisar 60\%-85\% (Soemarna, 2009). Oleh karena itu pembudidayaan rotan jernang akan diperoleh hasil maksimal apabila dilakukan di habitat alaminya. Jernang berpotensi untuk dilakukan integrasi di kebun karet. Kegiatan integrasi tersebut merupakan solusi yang tepat untuk meningkatkan produktivitas rotan jernang dan perekonomian petani karet di Mandiangin. Menurut Arifin (2010), bahwa berkebun jernang jauh lebih menguntungkan dari pada sawit dan karet. Di Desa Liam Lestari, terdapat kebun karet yang diintegrasi dengan jernang. Oleh karena itu jernang memiliki prospek yang baik untuk dikembangkan dalam skala besar.

\section{Perlindungan dan Pemagaran Pohon Induk Jernang}

Masyarakat di desa Liam Lestari selama ini belum membudidayakan tanaman jernang di kebunnya. Alasannya yaitu karena masyarakat takut bahwa jernang mereka nanti dicuri, Kekhawatiran terhadap pencurian itulah makanya selama ini mereka mengandalkan mencari jernang di hutan. Pemanenan buah jernang di Desa Liam Lestari pada saat buah masih muda mengakibatkan kesulitan untuk melakukan budidaya jernang melalui biji. Hal ini disebabkan karena seringnya terjadi pencurian pada buah jernang, sehingga pemilik jernang melakukan pemanenan dini. Sementara itu dengan semakin mudahnya dalam mengakses pasar jernang dan tingginya permintaan jernang menyebabkan harga jernang semakin tinggi. Dampaknya, masyarakat lebih intensif dalam memanen buah jernang (Mutenje et al., 2011). Semakin tingginya komersialisasi komoditi mengakibatkan keanekaragaman hayati termasuk jernang akan terancam (Lenzen et al., 2012). Kerusakan serta alih fungsi lahan mengakibatkan rusaknya habitat jernang, sehingga semakin lama populasinya akan semakin berkurang. Akhirnya hal ini dapat mengakibatkan menurunnya produksi dan untuk mendapatkan jernang akan semakin sulit. 
Perlindungan pohon induk jernang dilakukan di Desa Liam Lestari, karena hanya di desa ini terdapat kebun karet yang diintegrasi dengan jernang. Perlindungan pohon induk jernang dilakukan supaya tidak ada lagi pencurian buah jernang (Gambar 2), sehingga kita dapat memanen buah tua jernang sebagai sumber bibit. Sebelum dilakukan perlindungan pohon induk jernang, terjadi pencurian buah jernang dengan cara menebang pohon jernang sebanyak 5 batang, sehingga 8 tangkai buah jernang hilang dengan jumlah buah lebih kurang 1.000 buah (Gambar 2). Penebangan dan penarikan pohon jernang yang dicuri ini juga berdampak pada pohon disebelahnya. Akibatnya sebanyak 4 batang pohon jernang ikut tertarik ke bawah, sehingga 5 tangkai buah menjadi mati dan sebanyak sekitar 600 buah gugur (Gambar 3).

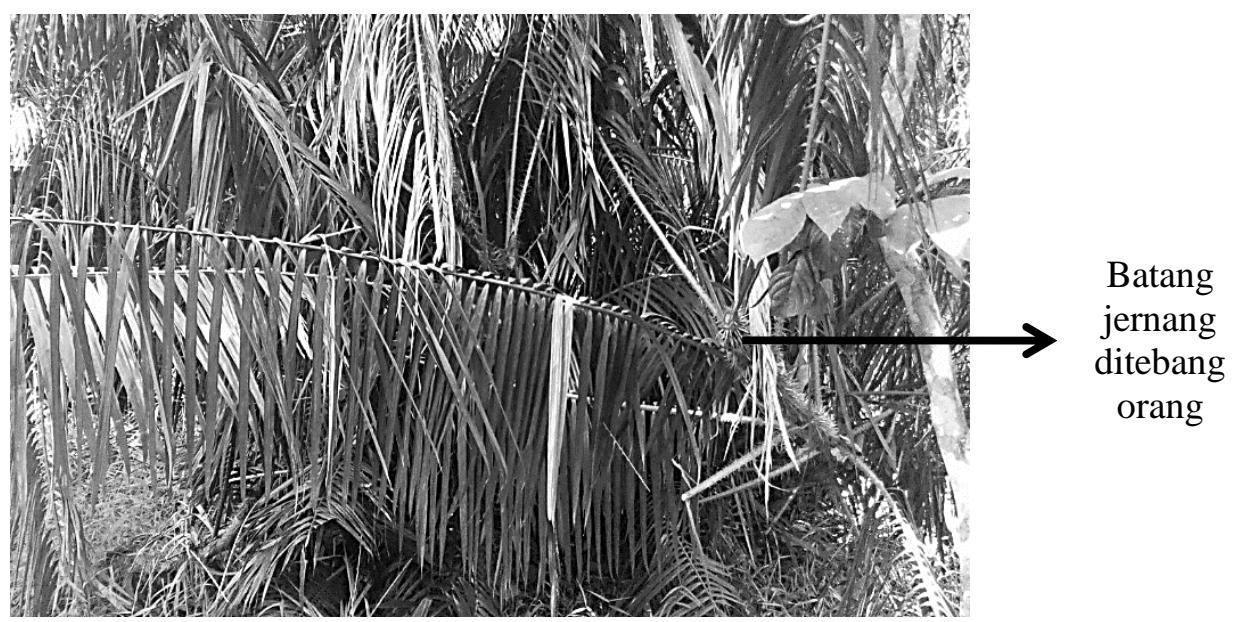

Gambar 2. Pencurian buah jernang dengan menebang batang jernang oleh orang yang tak dikenal

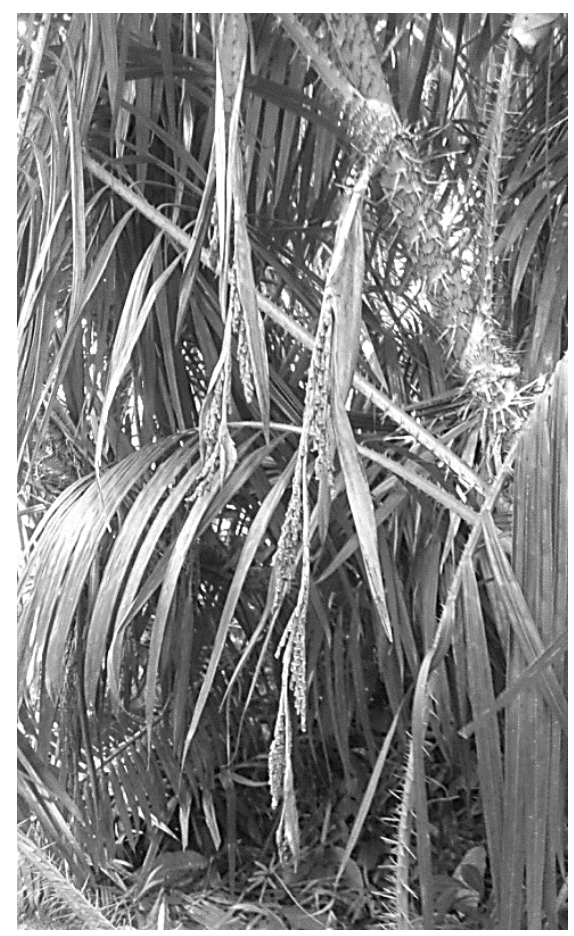

Gambar 3. Buah gugur akibat pohon tertarik karena penebangan batang jernang oleh orang yang tak dikenal

Oleh karena itu sangat penting dilakukan pemagaran jernang dibuat dengan menggunakan kayu bulian/kayu besi (Eusideroxylon zwageri) hal ini bertujuan supaya pagar yang dibuat lebih tahan lama (lebih 25 tahun) (Gambar 4). Di Jambi, bulian dapat ditemukan dalam 
populasi yang cukup besar pada beberapa kawasan hutan seperti kawasan hutan Senami, dengan luas areal 15.000 ha dan kawasan cagar alam Durian Luncuk I dan II masing-masing seluas 73.74 dan 41.37 ha serta kawasan hutan lain yang menjadi habitat bulian (Irawan, 2005). Habitat alami kayu bulian terutama di Pulau Sumatra dan Kalimantan (Irawan, 2015).

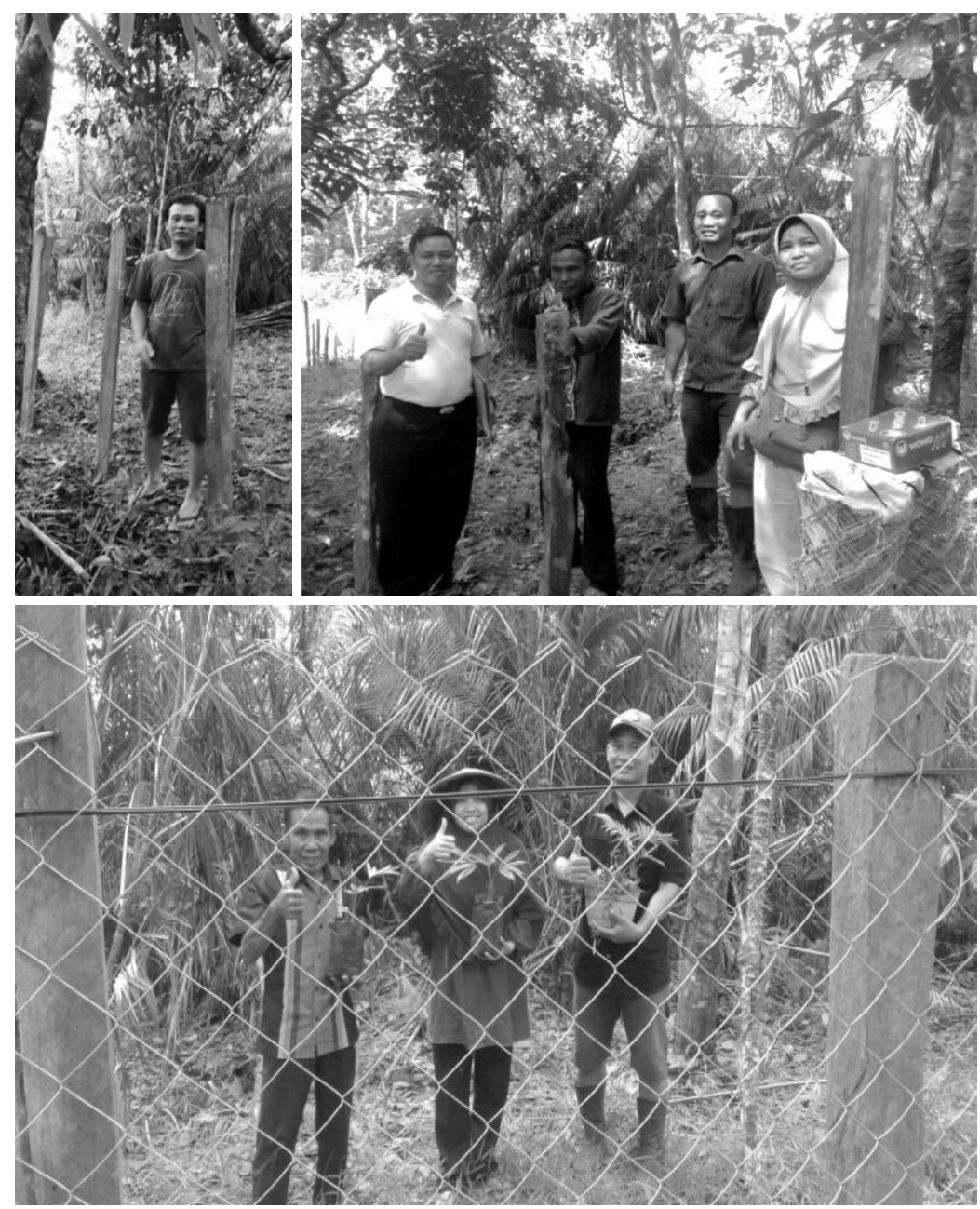

Gambar 4. Pemagaran pohon induk jernang dengan kayu besi/kayu bulian guna melindungi pohon Jernang

Menurut Penelitian yang dilakukan oleh Syafii et al. (1987), melaporkan bahwa dalam bulian terdapat komponen Eusiderin yang menentukan ketahanan kayu bulian. Komponen tersebut dapat ditemukan pada kayu teras. Selain itu, kayu bulian juga mempunyai serat dan dinding sel yang tebal serta sel mengandung senyawa ekstraktif sehingga tahan terhadap serangan rayap, serangga dan jamur tropis. Beberapa keunggulan kayu bulian yaitu (1) kayu kuat serta sangat awet (2) kemampuan bertunasnya yang sangat baik apabila akar utuh (3) karena pertumbuhannya lambat umur pohon panjang hingga ratusan tahun, (4) biji bersifat poliembrio (5) tahan kebakaran pada pohon bulian tua. Akan tetapi karena adanya penebangan pohon bulian yang kurang memperhatikan kelestariannya di mana pohon yang berdiameter kurang dari $50 \mathrm{~cm}$ telah ditebang, sehingga mengakibatkan semakin sulitnya memperoleh kayu bulian. Selain itu kebakaran hutan, konversi hutan menjadi perkebunan dan non hutan di mana pohon bulian yang tumbuh bersama jenis pohon dipterocarpa juga turut ditebang (Effendi, 2009). 


\section{KESIMPULAN}

Berdasarkan hasil pengabdian yang telah dilakukan dapat diambil kesimpulan bahwa sosialisasi tentang budidaya jernang di Mandiangin mendapat respon positif dari anggota kelompok tani. Hal tersebut dibuktikan dari antusiasme anggota kelompok tani mengikuti rangkaian kegiatan PPPUD dari awal hingga akhir dan antusiasme masyarakat di luar kelompok tani untuk melakukan budidaya jernang di kebun karetnya. Pelaksanaan kegiatan PPPUD pemagaran pohon induk jernang dengan kayu bulian dan kawat telah dilakukan dan berhasil mengatasi masalah pencurian terhadap buah jernang.

\section{UCAPAN TERIMA KASIH}

Terima kasih tidak terhingga kami sampaikan kepada Direktorat Riset dan Pengabdian Masyarakat, Direktorat Jenderal Penguatan Riset dan Pengembangan Kementerian Riset, Teknologi, dan Pendidikan Tinggi, sesuai dengan Perjanjian Pendanaan Pelaksanaan Program Pengabdian Kepada Masyarakat skim Program Pengembangan Produk Unggulan Daerah Nomor: 013/SP2H/PPM/DRPM/2018 tanggal 5 Desember 2017.

\section{Daftar Pustaka}

1. Arifin, W. (2010, January 27). Jernang: Tanaman Konservasi bernilai Ekonomis Tinggi dan Prospeknya di Provinsi Jambi. Retrieved from http://wein-arifin.blogspot.com/2009/01/jernangtanaman-konservasi

2. Asra, R., Syamsuardi, Mansyurdin, \& Witono, J.R. (2014). The study of genetic diversity of Daemonorops draco (Palmae) using ISSR markers. BIODIVERSITAS Journal of Biological Diversity, 15(2), 109-114. https://doi.org/10.13057/biodiv/d150201

3. Asra, R., Syamsuardi, Mansyurdin, \& Witono, J.R. (2018). Genetic diversity in Daemonorops draco (Willd.) Blume (Arecaceae) among wild and cultivated populations inferred by RAPD markers. SABRAO Journal Breeding Genetics, 50(2), 145-155.

4. Asra, R., Syamsuardi, Mansyurdin, \& Witono, J.R. (2012). Rasio Seks Jernang (Daemonorops Draco (Willd.) blume) Pada Populasi Alami Dan Budidaya: Implikasi Untuk Produksi Biji. Buletin Kebun Raya, 15(1), 1-9. https://doi.org/10.14203/bkr.v15i1.10

5. Balai Konservasi Sumber Daya Alam Jambi. (2010). Hasil hutan non-kayu Jambi Propinsi. Jambi, Indonesia: Departemen Kehutanan.

6. Effendi, R. (2009). Kayu Ulin di Kalimantan: Potensi, Manfaat, Permasalahan dan Kebijakan yang Diperlukan untuk Kelestariannya

7. Gupta, D., Bleakley, B., \& Gupta, R.K. (2008). Dragon's blood: botany, chemistry and therapeutic uses. Journal of Ethnopharmacology, 115(3): 361-380. https://doi.org/10.1016/j.jep.2007.10.018

8. Hisan. (2012). Strategi pengembangan pemanfaatan hasil hutan bukan kayu di Taman Nasional Bukit Tigapuluh wilayah Riau (Master Thesis). Universitas Andalas, Padang, Indonesia.

9. Irawan, B. (2005). Ironwood (Eusideroxylon zwageri Teijsm. \& Binn.) Diversity and Its Conservation inJambi, Indonesia. Paper presented at International Seminar on Biodiversity Conservation and Sustainable Use. Universitas Cendrawasih, Manokwari, Indonesia.

10. Irawan, B. (2015). Soil Properties and the Abundance of Ironwood (Eusideroxylon Zwageri Teijsm. \& Binn.) Varieties in Jambi, Indonesia. Jurnal Manajemen Hutan Tropika, 21(3), 155 161 .

11. Kementerian Kehutanan Republik Indonesia. (2013). Budidaya Tanaman Rotan Jernang (Daemonorops sp.). Jakarta, Indonesia: Pusat Penyuluhan Kehutanan. 
12. Lestari, S. (2017). Drago's Blood as the Communiy Life Support: Case of Muara Enim Regency, South Sumatra Province. Jurnal Penelitian Sosial dan Ekonomi Kehutanan, 14(3), 191-203. https://doi.org/10.20886/jpsek.2017.14.3.191-203

13. Lenzen, M., Moran, D., Kanemoto, K., Foran, B., Lobefaro, L., \& Geschke, A. (2012). International trade drives biodiversity threats in developing nations. Nature, 486, 109-112. https://doi.org/10.1038/nature11145

14. Matangaran, J.R., \& Puspitasari. (2012). Potensi dan Pemanenan Buah Rotan Jernang. Jurnal Silvikultur Tropika, 3(1), 140-148.

15. Mutenje, M.J., Ortmann, G.F., \& Ferrer, S.R.D. (2011). Management of non-timber forestry products extraction: Local institutions, ecological knowledge and market structure in SouthEastern Zimbabwe. Ecological Economics, 70(3), 454-461.

16. Purwanto, Y., Walujo, E.B., \& Afriastini. (2009). Analisis nilai kepentingan budaya hasil hutan bukan kayu untuk valuasi potensi dan kemungkinan pengembangannya. Bogor, Indonesia: LIPI.

17. Purwanto, Y., Polosakan, R., Susiarti, S., \& Walujo, E. (2005). Ekstraktivisme Jernang (Daemonorops spp) dan Kemungkinan Pengembangannya. Pusat Penelitian Biologi-LIPI.

18. Ridhwan, M., Andalia, N., Armil, \& Yuhasriati. (2018). Etnobotani Jernang Masyarakat Pedalaman Bireun. Biota, 11(2), 158168.

19. Soemarna, Y. (2009). Budidaya rotan jernang (Daemonorops draco Willd). Journal Litbang Kehutanan, 2(3), 5-10.

20. Sulasmi, I.S., Purwanto, Y., \& Fatimah, S. (2012). Rattan Jernang (Daemonorops draco) management by Anak Dalam Tribe in Jebak Batanghari, Jambi Province. Biodiversitas, 13(3), $152-162$.

21. Syafii, W., Samejima, M., \& Yoshimoto, T. (1987). The role of extractives in decay resistance of ulin (Eusideroxylon zwageri T. et B.). Bulletin of The Tokyo University Forests, 77, 1-8.

22. Waluyo, T.K., \& Pasaribu, G. (2015). Aktivitas Antijamur, Antibakteri dan Penyembuhan Luka Ekstrak Resin Jernang. Jurnal Penelitian Hasil Hutan, 33(4), 377-385.

23. Winarni, I., Sumadiwangsa, E.S., \& Setyawan, D. (2004). Pengaruh Tempat Tumbuh, Jenis dan Diameter Batang Terhadap Produktifitas Pohon Penghasil Biji Tengkawang. Jurnal Penelitian Hasil Hutan, 22(1), 23-33.

24. Yetty, Bambang, H., \& Pinta, M. (2013). Studi Etnobotani Jernang (Daemonorops spp.) pada Masyarakat Desa Lamban Sigatal dan Sepintun Kecamatan Pauh Kabupaten Sarolangun Jambi. Biospecies, 6(1). 